\title{
Pengelompokkan Produk Kemasan Yang Harus Dihindari Penderita Diabetes Menggunakan Algoritma K-Means Clustering
}

\author{
Nurul Husna, Farida Hanum, M. Fauzan Azrial \\ Program Studi Teknik Informatika, Fakultas Teknik Universitas Samudra Jalan Kampus Meurandeh Langsa, Aceh
}

\section{KEYWORDS}

Diabetes, K-Means Clustering, Gula

\section{CORRESPONDENCE}

E-mail: Nuruulhusna@gmail.com

faridahanum729@gmail.com

Fauzan.azrial@gmail.com

$\overline{-10}$

\section{A B S T R A C T}

Kurangnya pengetahuan masyarakat dalam pentingnya memperhatikan informasi nilai gizi yang terdapat di dalam suatu produk menyebabkan masyarakat tidak terhindar dari berbagai penyakit, salah satu nya seperti penyakit diabetes dimana penderita penyakit ini harus lebih memperhatikan kadar glukosa yang terdapat di dalam makanan dan minuman yang dikonsumsi. Penelitian ini bertujuan untuk mengelompokkan beberapa produk kemasan yang terdapat di dua minimarket Kota Langsa menjadi kelompok produk tinggi gula rendah natrium dan produk rendah gula tinggi natrium dimana produk tinggi gula ini adalah produk yang dapat dihindari penderita diabetes. Metode yang digunakan pada penelitian ini adalah metode K-Means yaitu metode yang digunakan untuk mencari data dalam clustering non-hierarchical, dimana clustering tersebut berusaha untuk mempartisi data yang terdapat didalamnya menjadi satu bentuk atau lebih kedalam suatu cluster/kelompok. Data yang digunakan dalam penelitian ini adalah data nilai gizi seperti jumlah lemak, protein, gula, dan natrium dalam setiap produk kemasan. Penelitian ini juga menggunakan software RStudio untuk mengolah data dengan metode K-Means. Hasil penelitian ini memiliki dua bentuk, yaitu pengelompokkan produk kedalam dua kategori yang dihitung secara manual dan pengelompokkan produk kedalam dua kategori menggunakan RStudio beserta grafik berbentuk Plot Scatter.

\section{PENDAHULUAN}

Pada saat ini, produk seperti makanan ringan dan minuman kemasan bukanlah hal yang asing bagi masyarakat karena termasuk kedalam makanan dan minuman favorit yang dijadikan teman jika kita sedang bersantai. Akan tetapi, perlu diketahui juga, bahwa kandungan didalam produk kemasan ini tidak selalu sehat. Terdapat beberapa bahan yang didalamnya mengandung nilai gizi yang berlebihan. Maka dari itu, diperlukan suatu teknologi yang dapat digunakan untuk mencari data, menghitung data, dan mengelompokkan suatu data. Data yang telah dikumpulkan dapat diolah menjadi sebuah informasi yang dapat digunakan dengan suatu metode untuk menggali manfaat dari nilai tersebut untuk mengetahui nilai gizi yang terdapat didalam produk kemasan. Nilai gizi tertinggi didalam produk kemasan yang paling banyak adalah kandungan untuk Diabetes. Jadi, kita perlu menganalisis data yang kita kumpulkan untuk melihat apakah kandungan didalam produk kemasan berbahaya atau tidak untuk seseorang yang menderita Diabetes1.

Pada tahun 2013, IDF (International Diabetes Federation) membuat estimasi bahwa jumlah penyakit diabetes yang diderita masyarakat didunia mencapai 382 juta orang. Dari 382juta orang yang tersebut, dapat diperkirakan bahwa sekitar 175 juta orang diantaranya belum terdiagnosa, sehingga dapat terancam bahwa penyakitnya akan berkembang tanpa disadari oleh si penderita, sehingga kita tidak bisa mencegah nya apabila diabetes tersebut sudah berkembang didalam diri kita. Dan diperkirakan penyakit ini dapat meningkat di setiap tahunnya. Di Indonesia sendiri jumlah penyakit diabetes sudah mencapai nilai yang cukup tinggi, yaitu 12 juta orang pada tahun 2013. Pada tahun 2007-2013 Riskesdas (Riset Kesehatan Dasar) melakuka survei pada setiap penduduk untuk menghitung jumlah proporsi penderita diabetes untuk usia 15 tahun keatas. Penyakit diabetes mengalami peningkatan karena penyakit ini disebut sebagai Silent Killer. Penyakit diabetes adalah suatu penyakit gangguan metabolic menahun yang ditandai dengan kadar glukosa dalam darah yang nilainya melebihi nilai normal untuk kadar glukosa yang harus dikonsumsi2.

Data mining adalah serangkaian proses yang digunakan untuk mencari dan mengumpulkan data untuk melakukan eksplorasi, seleksi, dan pemodelan dari beberapa bagian data untuk menemukan pola atau kecenderungan yang biasanya keberadaannya tidak diketahui4. Clustering adalah proses partisi terhadap data yang terdapat didalamnya kedalam grup yang 
memiliki objek yang sama karakteristik antar satu objek dengan objek yang lainnya 3. Algoritma K-Means merupakan salah satu metode yang digunakan untuk mencari data dalam clustering nonhierarchical, dimana clustering tersebut berusaha untuk mempartisi data yang terdapat didalamnya menjadi satu bentuk atau lebih kedalam suatu cluster/kelompok5.

Dengan adanya jurnal tentang pengelompokkan makanan ringan dan minuman kemasan berdasarkan informasi nilai gizi ini, maka pasien penderita diabetes dapat mengetahui nilai gizi yang terdapat didalam makanan ringan dan minuman kemasan, terutama mengenai kadar glukosa yang terkandung didalam makanan ringan atau minuman kemasan. Sehingga pasien penderita diabetes dapat memilih makanan atau minuman jenis apa yang bisa dinikmati dan makanan atau minuman jenis apa yang harus dihindari agar tingkat glukosa dalam darah tidak meningkat.

\section{METODOLOGI PENELITIAN}

\section{Jenis penelitian}

Jenis penelitian yang digunakan dalam penelitian ini adalah jenis penelitian terapan. Jenis penelitian terapan adalah sebuah penelitian yang digunakan untuk menghasilkan suatu objek agar bisa langsung diterapkan untuk mencari solusi dari suatu masalah. Dalam proyek ini, kami menggunakan metode k-means clustering yang digunakan untuk mengelompokkan produk kemasan berdasarkan informasi nilai gizi yang terdapat didalam produk kemasan tersebut. Data yang digunakan dalam penelitian ini diambil dari dua minimarket, yaitu minimarket Indomaret Kota Langsa dan minimarket saqina kota langsa.

\section{Metode pengumpulan data}

Jenis data yang digunakan dalam penelitian ini adalah jenis data kuantitatif. Data kuantitatif adalah jenis data yang dapat dihitung, yang berupa angka dan nominal. Lebih spesifik lagi data yang digunakan adalah data matriks, yaitu jenis data yang memiliki objek dan atribut didalamnya. Sumber data yang digunakan dalam penelitian adalah data primer. Sumber data primer merupakan sumber data yang diperoleh dari sumber asli dan diambil langsung ditempat tanpa melalui media perantara. Metode pengumpulan data yang digunakan dalam penelitian ini adalah dengan cara observasi. Observasi data dilakukan untuk mengumpulkan data untuk mendukung proses penelitian.

\section{Metode analisis data}

Metode analisis data yang digunakan dalam penelitian ini adalah metode analisis data dengan pendekatan kuantitatif. Pendekatan kuantitaif adalah pendekatan yang digunakan untuk membuat sebuah uraian yang sistematis terhadap objek yang digunakan dalam penelitian mengenai sifat-sifat dan fakta-fakta dari objek tersebut. Kemudian objek yang diteliti akan digabung.

untuk membuat hubungan antar variable yang terdapat didalamnya. Penelitian dengan pendekatan kuantitatif analisis data diambil dari data-data yang berbentuk numerik, sebuah data yang dapat dihitung.

\section{HASIL DAN PEMBAHASAN}

\section{Pengelompokan Data Manual}

Dari pembahasan pada jurnal ini, data yang digunakan adalah data informasi nilai gizi pada produk kemasan baik itu berupa makanan ataupun minuman. Hasil dan pembahasan data ini yaitu sebagai berikut:

1. Kumpulkan data informasi nilai gizi dari makanan dan minuman kemasan seperti pada tabel 1 dibawah ini

Tabel 1 Informasi Nilai Gizi Produk Kemasan.

\begin{tabular}{|c|c|c|c|c|c|}
\hline No. & Produk Kemasan & Lemak & Protein & Gula & Natrium \\
\hline 1 & Good Day & 3 & 0 & 22 & 0,055 \\
\hline 2 & White Coffee & 2 & 4 & 21 & 0,065 \\
\hline 3 & Golda & 2 & 2 & 15 & 0,105 \\
\hline 4 & Kopiko Kopi & 3 & 3 & 23 & 0,270 \\
\hline 5 & Nescafe Origin & 2 & 3 & 18 & 0,115 \\
\hline 6 & Del Monte Quality Vanilla & 3 & 2 & 21 & 0,105 \\
\hline 7 & Pepsi Blue & 0 & 0 & 34 & 0,015 \\
\hline 8 & Fruit Tea & 0 & 0 & 27 & 0,035 \\
\hline 9 & Stee & 0 & 0 & 26 & 0,025 \\
\hline 10 & Ichitan Thai Tea Milk Coffe & 5 & 4 & 29 & 0,220 \\
\hline 11 & Kratingdaeng & 0 & 1,5 & 25 & 0 \\
\hline 12 & Fanta Anggur & 0 & 0 & 25 & 0,055 \\
\hline 13 & Sprite & 0 & 0 & 25 & 0,045 \\
\hline 14 & Coca Cola & 0 & 0 & 27 & 0,015 \\
\hline 15 & Nutri Boost & 1 & 2 & 33 & 0,160 \\
\hline 16 & Minute Maid Pulpy & 0 & 0 & 27 & 0,045 \\
\hline 17 & Fresh Tea Marquisa & 0 & 0 & 26 & 0,030 \\
\hline 18 & Isoplus & 0 & 0 & 23 & 0,160 \\
\hline 19 & Indomilk Good To Go & 3,5 & 5 & 24 & 0,110 \\
\hline 20 & Coolant & 0 & 0 & 23 & 0,170 \\
\hline 21 & Oishi Ring Bee & 4,5 & 2 & 2 & 0,300 \\
\hline 22 & Stik Kentang Renova & 20 & 1 & 3 & 0,530 \\
\hline 23 & Gery Saluut & 5 & 1 & 5 & 0,120 \\
\hline 24 & Malkis Seaweed & 3,5 & 1 & 2 & 0,125 \\
\hline 25 & Hup Seng Cream Creackers & 3,5 & 3 & 2 & 2,400 \\
\hline 26 & Indomie & 12 & 8 & 6 & 0,680 \\
\hline 27 & Cap PingPong Sugar Creakers & 2 & 2 & 3 & 0,150 \\
\hline 28 & Shoon Fatt Sugar Creakers & 10 & 4 & 3 & 0,220 \\
\hline 29 & $\begin{array}{ccc}\text { Lavish } & \text { Peanut } & \text { Butter } \\
\text { Sandwich } & \end{array}$ & 9 & 3 & 8 & 0,840 \\
\hline 30 & Naiyu Jagung & 11 & 3 & 7 & 0,310 \\
\hline 31 & Mega Chocolate & 6 & 2 & 6 & 0,120 \\
\hline 32 & Hello Panda & 4,5 & 3 & 12 & 0,180 \\
\hline 33 & Pocky & 10 & 3 & 9 & 0,140 \\
\hline 34 & Ajinomoto YumYum & 12 & 5 & 5 & 2,050 \\
\hline 35 & Sukses & 10 & 13 & 9 & 1,190 \\
\hline 36 & Sarimi & 9 & 13 & 3 & 1,360 \\
\hline 37 & Bihun Rose Brand & 0 & 1 & 1 & 1,600 \\
\hline 38 & Sarimi Mie Gelas & 0 & 3 & 2 & 0,390 \\
\hline
\end{tabular}


2. Centroid awal

Langkah awal yang harus dilakukan dalam pengelompokkan data menggunakan algoritma KMeans Clustering adalah menentukan jumlah cluster. Dalam penelitian ini, data dikelompokkan menjadi 2 cluster. Setelah itu, menentukan titik pusat awal (centroid awal) dari setiap cluster secara random dari data yang ada. Pada penelitian ini, centroid awal diambil dari data ke-13 sebagai cluster 1 dan data ke26 sebagai cluster 2 seperti pada tabel dibawah ini.

Tabel 2 Centroid Awal

\begin{tabular}{|c|l|c|c|c|c|}
\hline No. & $\begin{array}{c}\text { Produk } \\
\text { Kemasan }\end{array}$ & Lemak & Protein & Gula & Natrium \\
\hline 13 & Sprite & 0,000 & 0,000 & 25,000 & 0,045 \\
\hline 26 & Indomie & 12,000 & 8,000 & 6,000 & 0,680 \\
\hline
\end{tabular}

3. Iterasi 1 Untuk menentukan jarak antar data dan pusat cluster, digunakan rumus Euclidian Distance dimana rumus ini menggunakan data dari Tabel 1 dan Tabel 2 dengan rumus dan perhitungan seperti dibawah ini.

$$
\begin{aligned}
& D(i, j) \\
& =\sqrt{\left(X_{1 i}-X_{1 j}\right)^{2}+\left(X_{2 i}-X_{2 j}\right)^{2}+\cdots+\left(X_{k i}-X_{k j}\right)^{2}}
\end{aligned}
$$

Dimana:

$\mathrm{D}(\mathrm{i}, \mathrm{j}) \quad=$ Jarak data ke-i ke pusat cluster $\mathrm{j}$

Xki = Data ke-i pada atribut data ke-k

$\mathrm{Xkj} \quad=$ Data ke-j pada atribut data ke-k

Jarak cluster 1 didapatkan dari data informasi nilai gizi produk kemasan dengan data ke-13 yang menjadi centroid awal untuk cluster 1 dan jarak cluster 2 didapatkan dari data informasi nilai gizi produk kemasan dengan data ke-26 yang menjadi centroid awal untuk cluster 2 seperti pada table dibawah ini

\section{Tabel 3 Iterasi 1 Cluster 1}

\begin{tabular}{|c|c|c|}
\hline No. & Perhitungan & Hasil \\
\hline 1 & $\sqrt{(3-0)^{2}+(0-0)^{2}+(22-25)^{2}+(0,055-0,045)^{2}}$ & 4,234 \\
\hline 2 & $\sqrt{(2-0)^{2}+(4-0)^{2}+(21-25)^{2}+(0,065-0,045)^{2}}$ & 6 \\
\hline 3 & $\sqrt{(2-0)^{2}+(2-0)^{2}+(15-25)^{2}+(0,105-0,045)^{2}}$ & 10,392 \\
\hline 4 & $\sqrt{(3-0)^{2}+(3-0)^{2}+(23-25)^{2}+(0,27-0,045)^{2}}$ & 4,696 \\
\hline 5 & $\sqrt{(2-0)^{2}+(3-0)^{2}+(18-25)^{2}+(0,115-0,045)^{2}}$ & 7,874 \\
\hline 6 & $\sqrt{(3-0)^{2}+(2-0)^{2}+(21-25)^{2}+(0,105-0,045)^{2}}$ & 5,385 \\
\hline 7 & $\sqrt{(0-0)^{2}+(0-0)^{2}+(34-25)^{2}+(0,015-0,045)^{2}}$ & 9 \\
\hline 8 & $\sqrt{(0-0)^{2}+(0-0)^{2}+(27-25)^{2}+(0,035-0,045)^{2}}$ & 2 \\
\hline 9 & $\sqrt{(0-0)^{2}+(0-0)^{2}+(26-25)^{2}+(0,025-0,045)^{2}}$ & 1 \\
\hline 10 & $\sqrt{(5-0)^{2}+(4-0)^{2}+(29-25)^{2}+(0,022-0,045)^{2}}$ & 7,552 \\
\hline 11 & $\sqrt{(0-0)^{2}+(1,5-0)^{2}+(25-25)^{2}+(0-0,045)^{2}}$ & 1,501 \\
\hline 12 & $\sqrt{(0-0)^{2}+(0-0)^{2}+(25-25)^{2}+(0,055-0,045)^{2}}$ & 0,01 \\
\hline
\end{tabular}

\begin{tabular}{|l|l|c|}
\hline 13 & $\sqrt{ }(0-0)^{2}+(0-0)^{2}+(25-25)^{2}+(0,045-0,045)^{2}$ & 0 \\
\hline 14 & $\sqrt{(0-0)^{2}+(0-0)^{2}+(27-25)^{2}+(0,015-0,045)^{2}}$ & 2 \\
\hline 15 & $\sqrt{(1-0)^{2}+(2-0)^{2}+(33-25)^{2}+(0,16-0,045)^{2}}$ & 8,307 \\
\hline 16 & $\sqrt{ }(0-0)^{2}+(0-0)^{2}+(27-25)^{2}+(0,045-0,045)^{2}$ & 2 \\
\hline 17 & $\sqrt{(0-0)^{2}+(0-0)^{2}+(26-25)^{2}+(0,03-0,045)^{2}}$ & 1 \\
\hline 18 & $\sqrt{(0-0)^{2}+(0-0)^{2}+(23-25)^{2}+(0,16-0,045)^{2}}$ & 2 \\
\hline 19 & $\sqrt{(3,5-0)^{2}+(5-0)^{2}+(24-25)^{2}+(0,11-0,045)^{2}}$ & 6,185 \\
\hline 20 & $\sqrt{(0-0)^{2}+(0-0)^{2}+(23-25)^{2}+(0,17-0,045)^{2}}$ & 2,004 \\
\hline 21 & $\sqrt{(4,5-0)^{2}+(2-0)^{2}+(2-25)^{2}+(0,3-0,045)^{2}}$ & 23,523 \\
\hline 22 & $\sqrt{(20-0)^{2}+(1-0)^{2}+(3-25)^{2}+(1-0,045)^{2}}$ & 29,753 \\
\hline 23 & $\sqrt{(5-0)^{2}+(1-0)^{2}+(5-25)^{2}+(0,12-0,045)^{2}}$ & 20,640 \\
\hline 24 & $\sqrt{(3,5-0)^{2}+(1-0)^{2}+(2-25)^{2}+(0,125-0,045)^{2}}$ & 23,286 \\
\hline 25 & $\sqrt{(3,5-0)^{2}+(3-0)^{2}+(2-25)^{2}+(2,4-0,045)^{2}}$ & 23,575 \\
\hline 26 & $\sqrt{(12-0)^{2}+(8-0)^{2}+(6-25)^{2}+(0,68-0,045)^{2}}$ & 23,862 \\
\hline 27 & $\sqrt{(2-0)^{2}+(2-0)^{2}+(3-25)^{2}+(0,15-0,045)^{2}}$ & 22,181 \\
\hline 28 & $\sqrt{(10-0)^{2}+(4-0)^{2}+(3-25)^{2}+(0,22-0,045)^{2}}$ & 24,496 \\
\hline 29 & $\sqrt{(9-0)^{2}+(3-0)^{2}+(8-25)^{2}+(0,84-0,045)^{2}}$ & 19,484 \\
\hline 30 & $\sqrt{(11-0)^{2}+(3-0)^{2}+(7-25)^{2}+(0,31-0,045)^{2}}$ & 21,309 \\
\hline 31 & $\sqrt{(6-0)^{2}+(2-0)^{2}+(6-25)^{2}+(0,12-0,045)^{2}}$ & 20,025 \\
\hline 32 & $\sqrt{(4,5-0)^{2}+(3-0)^{2}+(12-25)^{2}+(0,18-0,045)^{2}}$ & 14,081 \\
\hline 33 & $\sqrt{(10-0)^{2}+(3-0)^{2}+(9-25)^{2}+(0,14-0,045)^{2}}$ & 19,105 \\
\hline 34 & $\sqrt{(12-0)^{2}+(5-0)^{2}+(5-25)^{2}+(2,05-0,045)^{2}}$ & 23,938 \\
\hline 35 & $\sqrt{(10-0)^{2}+(13-0)^{2}+(9-25)^{2}+(1,19-0,045)^{2}}$ & 22,941 \\
\hline 36 & $\sqrt{(9-0)^{2}+(13-0)^{2}+(3-25)^{2}+(1,36-0,045)^{2}}$ & 27,124 \\
\hline 37 & $\sqrt{(0-0)^{2}+(1-0)^{2}+(1-25)^{2}+(1,6-0,045)^{2}}$ & 24,071 \\
\hline 38 & $\sqrt{(0-0)^{2}+(3-0)^{2}+(2-25)^{2}+(0,39-0,045)^{2}}$ & 23,197 \\
\hline
\end{tabular}

\begin{tabular}{|c|c|c|}
\hline No. & Perhitungan & Hasil \\
\hline 1 & $\sqrt{(3-12)^{2}+(0-8)^{2}+(22-25)^{2}+(0,055-0,68)^{2}}$ & 20,035 \\
\hline 2 & $\sqrt{(2-12)^{2}+(4-8)^{2}+(21-25)^{2}+(0,065-0,68)^{2}}$ & 18,476 \\
\hline 3 & $\sqrt{(2-12)^{2}+(2-8)^{2}+(15-25)^{2}+(0,105-0,68)^{2}}$ & 14,742 \\
\hline 4 & $\sqrt{(3-12)^{2}+(3-8)^{2}+(23-25)^{2}+(0,27-0,68)^{2}}$ & 19,879 \\
\hline 5 & $\sqrt{(2-12)^{2}+(3-8)^{2}+(18-25)^{2}+(0,115-0,68)^{2}}$ & 16,411 \\
\hline 6 & $\sqrt{(3-12)^{2}+(2-8)^{2}+(21-25)^{2}+(0,105-0,68)^{2}}$ & 18,502 \\
\hline 7 & $\sqrt{(0-12)^{2}+(0-8)^{2}+(34-25)^{2}+(0,015-0,68)^{2}}$ & 31,503 \\
\hline 8 & $\sqrt{(0-12)^{2}+(0-8)^{2}+(27-25)^{2}+(0,035-0,68)^{2}}$ & 25,484 \\
\hline 9 & $\sqrt{(0-12)^{2}+(0-8)^{2}+(26-25)^{2}+(0,025-0,68)^{2}}$ & 24,666 \\
\hline 10 & $\sqrt{(5-12)^{2}+(4-8)^{2}+(29-25)^{2}+(0,022-0,68)^{2}}$ & 24,376 \\
\hline 11 & $\sqrt{ }(0-12)^{2}+(1,5-8)^{2}+(25-25)^{2}+(0-0,68)^{2}$ & 23,403 \\
\hline 12 & $\sqrt{(0-12)^{2}+(0-8)^{2}+(25-25)^{2}+(0,055-0,68)^{2}}$ & 23,862 \\
\hline 13 & $\sqrt{(0-12)^{2}+(0-8)^{2}+(25-25)^{2}+(0,045-0,68)^{2}}$ & 23,862 \\
\hline 14 & $\sqrt{(0-12)^{2}+(0-8)^{2}+(27-25)^{2}+(0,015-0,68)^{2}}$ & 25,484 \\
\hline 15 & $\sqrt{(1-12)^{2}+(2-8)^{2}+(33-25)^{2}+(0,16-0,68)^{2}}$ & 29,770 \\
\hline 16 & $\sqrt{(0-12)^{2}+(0-8)^{2}+(27-25)^{2}+(0,045-0,68)^{2}}$ & 25,483 \\
\hline 17 & $\sqrt{(0-12)^{2}+(0-8)^{2}+(26-25)^{2}+(0,03-0,68)^{2}}$ & 24,666 \\
\hline 18 & $\sqrt{(0-12)^{2}+(0-8)^{2}+(23-25)^{2}+(0,16-0,68)^{2}}$ & 22,300 \\
\hline 19 & $\sqrt{(3,5-12)^{2}+(5-8)^{2}+(24-25)^{2}+(0,11-0,68)^{2}}$ & 20,139 \\
\hline 20 & $\sqrt{(0-12)^{2}+(0-8)^{2}+(23-25)^{2}+(0,17-0,68)^{2}}$ & 22,299 \\
\hline 21 & $\sqrt{(4,5-12)^{2}+(2-8)^{2}+(2-25)^{2}+(0,3-0,68)^{2}}$ & 11,046 \\
\hline 22 & $\sqrt{(20-12)^{2}+(1-8)^{2}+(3-25)^{2}+(1-0,68)^{2}}$ & 11,046 \\
\hline 23 & $\sqrt{(5-12)^{2}+(1-8)^{2}+(5-25)^{2}+(0,12-0,68)^{2}}$ & 9,966 \\
\hline 24 & $\sqrt{(3,5-12)^{2}+(1-8)^{2}+(2-25)^{2}+(0,125-0,68)^{2}}$ & 11,729 \\
\hline 25 & $\sqrt{(3,5-12)^{2}+(3-8)^{2}+(2-25)^{2}+(2,4-0,68)^{2}}$ & 10,78 \\
\hline 26 & $\sqrt{(12-12)^{2}+(8-8)^{2}+(6-25)^{2}+(0,68-0,68)^{2}}$ & 0 \\
\hline 27 & $\sqrt{(2-12)^{2}+(2-8)^{2}+(3-25)^{2}+(0,15-0,68)^{2}}$ & 12,053 \\
\hline 28 & $\sqrt{(10-12)^{2}+(4-8)^{2}+(3-25)^{2}+(0,22-0,68)^{2}}$ & 5,405 \\
\hline 29 & $\sqrt{(9-12)^{2}+(3-8)^{2}+(8-25)^{2}+(0,84-0,68)^{2}}$ & 6,166 \\
\hline 30 & $\sqrt{(11-12)^{2}+(3-8)^{2}+(7-25)^{2}+(0,31-0,68)^{2}}$ & 5,209 \\
\hline 31 & $\sqrt{(6-12)^{2}+(2-8)^{2}+(6-25)^{2}+(0,12-0,68)^{2}}$ & 8,504 \\
\hline 32 & $\sqrt{(4,5-12)^{2}+(3-8)^{2}+(12-25)^{2}+(0,18-0,68)^{2}}$ & 10,84 \\
\hline 33 & $\sqrt{(10-12)^{2}+(3-8)^{2}+(9-25)^{2}+(0,14-0,68)^{2}}$ & 6,188 \\
\hline 34 & $\sqrt{(12-12)^{2}+(5-8)^{2}+(5-25)^{2}+(2,05-0,68)^{2}}$ & 3,446 \\
\hline 35 & $\sqrt{(10-12)^{2}+(13-8)^{2}+(9-25)^{2}+(1,19-0,68)^{2}}$ & 6,185 \\
\hline 36 & $\sqrt{(9-12)^{2}+(13-8)^{2}+(3-25)^{2}+(1,36-0,68)^{2}}$ & 6,593 \\
\hline 37 & $\sqrt{(0-12)^{2}+(1-8)^{2}+(1-25)^{2}+(1,6-0,68)^{2}}$ & 14,793 \\
\hline 38 & $\sqrt{(0-12)^{2}+(3-8)^{2}+(2-25)^{2}+(0,39-0,68)^{2}}$ & 13,605 \\
\hline
\end{tabular}

Tabel 4 Iterasi 1 Cluster 2

Dari tabel diatas, maka didapatkan hasil iterasi 1 dari perhitungan data informasi nilai gizi produk kemasan dengan data centroid awal cluster 1 dan cluster 2. Langkah selanjutnya adalah menentukan jarak terdekat seperti pada tabel dibawah ini 
Tabel 5 Tabel Iterasi 1

\begin{tabular}{|c|c|c|c|c|c|c|c|c|}
\hline No. & $\begin{array}{l}\text { Produk } \\
\text { Kemasan }\end{array}$ & Lemak & Protein & Gula & Natrium & $\begin{array}{c}\text { Cluster } \\
1\end{array}$ & $\begin{array}{c}\text { Cluster } \\
2\end{array}$ & $\begin{array}{c}\text { Jarak } \\
\text { Terdekat }\end{array}$ \\
\hline 1 & Good Day & 3 & 0 & 22 & 0,055 & 4,234 & 20,035 & 4,234 \\
\hline 2 & White Coffee & 2 & 4 & 21 & 0,065 & 6 & 18,476 & 6 \\
\hline 3 & Golda & 2 & 2 & 15 & 0,105 & 10,392 & 14,742 & 10,392 \\
\hline 4 & Kopiko Kopi & 3 & 3 & 23 & 0,270 & 4,696 & 19,879 & 4,696 \\
\hline 5 & Nescafe Origin & 2 & 3 & 18 & 0,115 & 7,874 & 16,411 & 7,874 \\
\hline 6 & $\begin{array}{l}\text { Del Monte Quality } \\
\text { Vanilla }\end{array}$ & 3 & 2 & 21 & 0,105 & 5,385 & 18,502 & 5,385 \\
\hline 7 & Pepsi Blue & 0 & 0 & 34 & 0,015 & 9 & 31,503 & 9 \\
\hline 8 & Fruit Tea & 0 & 0 & 27 & 0,035 & 2 & 25,484 & 2 \\
\hline 9 & Stee & 0 & 0 & 26 & 0,025 & 1 & 24,666 & 1 \\
\hline 10 & $\begin{array}{l}\text { Ichitan ThaiTeaMilk } \\
\text { Coffe }\end{array}$ & 5 & 4 & 29 & 0,220 & 7,552 & 24,376 & 7,552 \\
\hline 11 & Kratingdaeng & 0 & 1,5 & 25 & 0,000 & 1,501 & 23,403 & 1,501 \\
\hline 12 & Fanta Anggur & 0 & 0 & 25 & 0,055 & 0,01 & 23,862 & 0,01 \\
\hline 13 & Sprite & 0 & 0 & 25 & 0,045 & 0 & 23,862 & 0 \\
\hline 14 & Coca Cola & 0 & 0 & 27 & 0,015 & 2 & 25,484 & 2 \\
\hline 15 & Nutri Boost & 1 & 2 & 33 & 0,160 & 8,307 & 29,770 & 8,307 \\
\hline 16 & Minute Maid Pulpy & 0 & 0 & 27 & 0,045 & 2 & 25,483 & 2 \\
\hline 17 & Fresh Tea Marquisa & 0 & 0 & 26 & 0,030 & 1 & 24,666 & 1 \\
\hline 18 & Isoplus & 0 & 0 & 23 & 0,160 & 2 & 22,300 & 2 \\
\hline 19 & Indomilk GoodToGo & 3,5 & 5 & 24 & 0,110 & 6,185 & 20,139 & 6,185 \\
\hline 20 & Coolant & 0 & 0 & 23 & 0,170 & 2,004 & 22,299 & 2,004 \\
\hline 21 & Oishi Ring Bee & 4,5 & 2 & 2 & 0,300 & 23,523 & 11,046 & 11,046 \\
\hline 22 & Stik Kentang Renova & 20 & 1 & 3 & 0,530 & 29,753 & 11,046 & 11,046 \\
\hline 23 & Gery Saluut & 5 & 1 & 5 & 0,120 & 20,640 & 9,966 & 9,966 \\
\hline 24 & Malkis Seaweed & 3,5 & 1 & 2 & 0,125 & 23,286 & 11,729 & 11,729 \\
\hline 25 & $\begin{array}{l}\text { Hup Seng Cream } \\
\text { Creackers }\end{array}$ & 3,5 & 3 & 2 & 2,400 & 23,575 & 10,78 & 10,78 \\
\hline 26 & Indomie & 12 & 8 & 6 & 0,680 & 23,862 & 0 & 0 \\
\hline 27 & $\begin{array}{l}\text { Cap PingPong Sugar } \\
\text { Creakers }\end{array}$ & 2 & 2 & 3 & 0,150 & 22,181 & 12,053 & 12,053 \\
\hline 28 & $\begin{array}{l}\text { Shoon Fatt Sugar } \\
\text { Creakers }\end{array}$ & 10 & 4 & 3 & 0,220 & 24,496 & 5,405 & 5,405 \\
\hline 29 & $\begin{array}{l}\text { Lavish Peanut Butter } \\
\text { Sandwich }\end{array}$ & 9 & 3 & 8 & 0,840 & 19,484 & 6,166 & 6,166 \\
\hline 30 & Naiyu Jagung & 11 & 3 & 7 & 0,310 & 21,309 & 5,209 & 5,209 \\
\hline
\end{tabular}


Data diatas akan dikelompokkan ke dalam 2 kelompok yaitu kelompok cluster 1 dan cluster 2 dimana nilai 1 menandakan data tersebut berada di kelompok itu. Lebih jelasnya dapat dilihat pada tabel dibawah ini:

Tabel 6 Pengelompokkan Data 1

\begin{tabular}{|c|c|c|}
\hline No. & $\begin{array}{c}\text { Cluster } \\
1\end{array}$ & $\begin{array}{c}\text { Cluster } \\
\quad 2\end{array}$ \\
\hline 1 & 1 & 0 \\
\hline 2 & 1 & 0 \\
\hline 3 & 1 & 0 \\
\hline 4 & 1 & 0 \\
\hline 5 & 1 & 0 \\
\hline 6 & 1 & 0 \\
\hline 7 & 1 & 0 \\
\hline 8 & 1 & 0 \\
\hline 9 & 1 & 0 \\
\hline 10 & 1 & 0 \\
\hline 11 & 1 & 0 \\
\hline 12 & 1 & 0 \\
\hline 13 & 1 & 0 \\
\hline 14 & 1 & 0 \\
\hline 15 & 1 & 0 \\
\hline 16 & 1 & 0 \\
\hline 17 & 1 & 0 \\
\hline 18 & 1 & 0 \\
\hline 19 & 1 & 0 \\
\hline 20 & 1 & 0 \\
\hline 21 & 0 & 1 \\
\hline 22 & 0 & 1 \\
\hline 23 & 0 & 1 \\
\hline 24 & 0 & 1 \\
\hline 25 & 0 & 1 \\
\hline 26 & 0 & 1 \\
\hline 27 & 0 & 1 \\
\hline 28 & 0 & 1 \\
\hline 29 & 0 & 1 \\
\hline 30 & 0 & 1 \\
\hline 31 & 0 & 1 \\
\hline 32 & 0 & 1 \\
\hline 33 & 0 & 1 \\
\hline 34 & 0 & 1 \\
\hline 35 & 0 & 1 \\
\hline 36 & 0 & 1 \\
\hline 37 & 0 & 1 \\
\hline 38 & 0 & 1 \\
\hline
\end{tabular}

4. Iterasi 2

Langkah selanjutnya adalah, menentukan kembali titik pusat cluster yang baru (centroid baru) dengan rumus rata-rata untuk data setiap cluster nya. Setelah dilakukan perhitungan, maka didapatkan hasil seperti dibawah ini.

Selanjutnya, dilakukan perhitungan iterasi kembali seperti pada langkah ke-3 dengan centroid baru dan data cluster yang sudah dikelompokkan. Hal ini dilakukan hingga centroid dari setiap cluster tidak mengalami perubahan lagi dan data tidak berpindah
Tabel 7 Centoid baru

\begin{tabular}{l|c|c|c|}
\cline { 2 - 4 } & Nilai Gizi & C1 & C2 \\
\cline { 2 - 4 } & Lemak & 1,225 & 7,333 \\
\cline { 2 - 4 } & Protein & 1,325 & 3,944 \\
\cline { 2 - 4 } $\begin{array}{l}\text { dari satu } \\
\text { tempat }\end{array}$ & Gula & 24,7 & 4,889 \\
\cline { 2 - 4 } & Natrium & 0,09 & 0,706 \\
\cline { 2 - 3 } & $\begin{array}{r}\text { tempat ke } \\
\text { lainnya }\end{array}$
\end{tabular}

lagi. Perhitungan iterasi dapat dilihat di tabel dibawah ini.

Tabel 8 Iterasi 2 Cluster 1

\begin{tabular}{|c|c|c|}
\hline No. & Perhitungan & Hasil \\
\hline 1 & $\sqrt{(3-1,225)^{2}+(0-1,325)^{2}+(22-24,7)^{2}+(0,055-0,09)^{2}}$ & 3,492 \\
\hline 2 & $\sqrt{ }(2-1,225)^{2}+(4-1,325)^{2}+(21-24,7)^{2}+(0,065-0,09)^{2}$ & 4,631 \\
\hline 3 & $\sqrt{(2-1,225)^{2}+(2-1,325)^{2}+(15-24,7)^{2}+(0,105-0,09)^{2}}$ & 9,754 \\
\hline 4 & $\sqrt{(3-1,225)^{2}+(3-1,325)^{2}+(23-24,7)^{2}+(0,27-0,09)^{2}}$ & 2,980 \\
\hline 5 & $\sqrt{(2-1,225)^{2}+(3-1,325)^{2}+(18-24,7)^{2}+(0,115-0,09)^{2}}$ & 6,950 \\
\hline 6 & $\sqrt{(3-1,225)^{2}+(2-1,325)^{2}+(21-24,7)^{2}+(0,105-0,09)^{2}}$ & 4,159 \\
\hline 7 & $\sqrt{(0-1,225)^{2}+(0-1,325)^{2}+(34-24,7)^{2}+(0,015-0,09)^{2}}$ & 9,474 \\
\hline 8 & $\sqrt{(0-1,225)^{2}+(0-1,325)^{2}+(27-24,7)^{2}+(0,035-0,09)^{2}}$ & 2,924 \\
\hline 9 & $\sqrt{(0-1,225)^{2}+(0-1,325)^{2}+(26-24,7)^{2}+(0,025-0,09)^{2}}$ & 2,225 \\
\hline 10 & $\sqrt{(5-1,225)^{2}+(4-1,325)^{2}+(29-24,7)^{2}+(0,022-0,09)^{2}}$ & 6,318 \\
\hline 11 & $\sqrt{ }(0-1,225)^{2}+(1,5-1,325)^{2}+(25-24,7)^{2}+(0-0,09)^{2}$ & 1,276 \\
\hline 12 & $\sqrt{ }(0-1,225)^{2}+(0-1,325)^{2}+(25-24,7)^{2}+(0,055-0,09)^{2}$ & 1,830 \\
\hline 13 & $\sqrt{(0-1,225)^{2}+(0-1,325)^{2}+(25-24,7)^{2}+(0,045-0,09)^{2}}$ & 1,830 \\
\hline 14 & $\sqrt{ }(0-1,225)^{2}+(0-1,325)^{2}+(27-24,7)^{2}+(0,015-0,09)^{2}$ & 2,924 \\
\hline 15 & $\sqrt{(1-1,225)^{2}+(2-1,325)^{2}+(33-24,7)^{2}+(0,16-0,09)^{2}}$ & 8,331 \\
\hline 16 & $\sqrt{(0-1,225)^{2}+(0-1,325)^{2}+(27-24,7)^{2}+(0,045-0,09)^{2}}$ & 2,924 \\
\hline 17 & $\sqrt{ }(0-1,225)^{2}+(0-1,325)^{2}+(26-24,7)^{2}+(0,03-0,09)^{2}$ & 2,225 \\
\hline 18 & $\sqrt{(0-1,225)^{2}+(0-1,325)^{2}+(23-24,7)^{2}+(0,16-0,09)^{2}}$ & 2,480 \\
\hline 19 & $\sqrt{(3,5-1,225)^{2}+(5-1,325)^{2}+(24-24,7)^{2}+(0,11-0,09)^{2}}$ & 4,379 \\
\hline 20 & $\sqrt{(0-1,225)^{2}+(0-1,325)^{2}+(23-24,7)^{2}+(0,17-0,09)^{2}}$ & 2,480 \\
\hline 21 & $\sqrt{(4,5-1,225)^{2}+(2-1,325)^{2}+(2-24,7)^{2}+(0,3-0,09)^{2}}$ & 22,946 \\
\hline 22 & $\sqrt{(20-1,225)^{2}+(1-1,325)^{2}+(3-24,7)^{2}+(1-0,09)^{2}}$ & 28,700 \\
\hline 23 & $\sqrt{ }(5-1,225)^{2}+(1-1,325)^{2}+(5-24,7)^{2}+(0,12-0,09)^{2}$ & 20,061 \\
\hline 24 & $\sqrt{(3,5-1,225)^{2}+(1-1,325)^{2}+(2-24,7)^{2}+(0,125-0,09)^{2}}$ & 22,816 \\
\hline 25 & $\sqrt{ }(3,5-1,225)^{2}+(3-1,325)^{2}+(2-24,7)^{2}+(2,4-0,09)^{2}$ & 22,991 \\
\hline 26 & $\sqrt{(12-1,225)^{2}+(8-1,325)^{2}+(6-24,7)^{2}+(0,68-0,09)^{2}}$ & 22,599 \\
\hline 27 & $\sqrt{ }(2-1,225)^{2}+(2-1,325)^{2}+(3-24,7)^{2}+(0,15-0,09)^{2}$ & 21,724 \\
\hline 28 & $\sqrt{(10-1,225)^{2}+(4-1,325)^{2}+(3-24,7)^{2}+(0,22-0,09)^{2}}$ & 23,560 \\
\hline 29 & $\sqrt{(9-1,225)^{2}+(3-1,325)^{2}+(8-24,7)^{2}+(0,84-0,09)^{2}}$ & 18,512 \\
\hline 30 & $\sqrt{(11-1,225)^{2}+(3-1,325)^{2}+(7-24,7)^{2}+(0,31-0,09)^{2}}$ & 20,290 \\
\hline 31 & $\sqrt{ }(6-1,225)^{2}+(2-1,325)^{2}+(6-24,7)^{2}+(0,12-0,09)^{2}$ & 19,312 \\
\hline 32 & $\sqrt{(4,5-1,225)^{2}+(3-1,325)^{2}+(12-24,7)^{2}+(0,18-0,09)^{2}}$ & 13,222 \\
\hline 33 & $\sqrt{(10-1,225)^{2}+(3-1,325)^{2}+(9-24,7)^{2}+(0,14-0,09)^{2}}$ & 18,064 \\
\hline 34 & $\sqrt{(12-1,225)^{2}+(5-1,325)^{2}+(5-24,7)^{2}+(2,05-0,09)^{2}}$ & 22,837 \\
\hline 35 & $\sqrt{(10-1,225)^{2}+(13-1,325)^{2}+(9-24,7)^{2}+(1,19-0,09)^{2}}$ & 21,471 \\
\hline 36 & $\sqrt{(9-1,225)^{2}+(13-1,325)^{2}+(3-24,7)^{2}+(1,36-0,09)^{2}}$ & 25,870 \\
\hline 37 & $\sqrt{(0-1,225)^{2}+(1-1,325)^{2}+(1-24,7)^{2}+(1,6-0,09)^{2}}$ & 23,782 \\
\hline 38 & $\sqrt{\left((0-1,225)^{2}+(3-1,325)^{2}+(2-24,7)^{2}+(0,39-0,09)^{2}\right.}$ & 22,797 \\
\hline
\end{tabular}

Tabel 9 Iterasi 2 Cluster 2

\begin{tabular}{|c|l|c|}
\hline No. & \multicolumn{1}{|c|}{ Perhitungan } & Hasil \\
\hline 1 & $\sqrt{(3-7,333)^{2}+(0-3,944)^{2}+(22-4,889)^{2}+(0,055-0,706)^{2}}$ & 3,492 \\
\hline 2 & $\sqrt{(2-7,333)^{2}+(4-3,944)^{2}+(21-4,889)^{2}+(0,065-0,706)^{2}}$ & 4,631 \\
\hline 3 & $\sqrt{(2-7,333)^{2}+(2-3,944)^{2}+(15-4,889)^{2}+(0,105-0,706)^{2}}$ & 9,754 \\
\hline 4 & $\sqrt{(3-7,333)^{2}+(3-3,944)^{2}+(23-4,889)^{2}+(0,27-0,706)^{2}}$ & 2,980 \\
\hline 5 & $\sqrt{(2-7,333)^{2}+(3-3,944)^{2}+(18-4,889)^{2}+(0,115-0,706)^{2}}$ & 6,950 \\
\hline 6 & $\sqrt{(3-7,333)^{2}+(2-3,944)^{2}+(21-4,889)^{2}+(0,105-0,706)^{2}}$ & 4,159 \\
\hline 7 & $\sqrt{(0-7,333)^{2}+(0-3,944)^{2}+(34-4,889)^{2}+(0,015-0,706)^{2}}$ & 9,474 \\
\hline 8 & $\sqrt{(0-7,333)^{2}+(0-3,944)^{2}+(27-4,889)^{2}+(0,035-0,706)^{2}}$ & 2,924 \\
\hline 9 & $\sqrt{(0-7,333)^{2}+(0-3,944)^{2}+(26-4,889)^{2}+(0,025-0,706)^{2}}$ & 2,225 \\
\hline 10 & $\sqrt{ }(5-7,333)^{2}+(4-3,944)^{2}+(29-4,889)^{2}+(0,022-0,706)^{2}$ & 6,318 \\
\hline 11 & $\sqrt{(0-7,333)^{2}+(1,5-3,944)^{2}+(25-4,889)^{2}+(0-0,706)^{2}}$ & 1,276 \\
\hline 12 & $\sqrt{(0-7,333)^{2}+(0-3,944)^{2}+(25-4,889)^{2}+(0,055-0,706)^{2}}$ & 1,830 \\
\hline
\end{tabular}




\begin{tabular}{|c|c|c|}
\hline 13 & $\sqrt{(0-7,333)^{2}+(0-3,944)^{2}+(25-4,889)^{2}+(0,045-0,706)^{2}}$ & 1,830 \\
\hline 14 & $\sqrt{(0-7,333)^{2}+(0-3,944)^{2}+(27-4,889)^{2}+(0,015-0,706)^{2}}$ & 2,924 \\
\hline 15 & $\sqrt{(1-7,333)^{2}+(2-3,944)^{2}+(33-4,889)^{2}+(0,16-0,706)^{2}}$ & 8,331 \\
\hline 16 & $\sqrt{ }(0-7,333)^{2}+(0-3,944)^{2}+(27-4,889)^{2}+(0,045-0,706)^{2}$ & 2,924 \\
\hline 17 & $\sqrt{ }(0-7,333)^{2}+(0-3,944)^{2}+(26-4,889)^{2}+(0,03-0,706)^{2}$ & 2,225 \\
\hline 18 & $\sqrt{(0-7,333)^{2}+(0-3,944)^{2}+(23-4,889)^{2}+(0,16-0,706)^{2}}$ & 2,480 \\
\hline 19 & $\sqrt{(3,5-7,333)^{2}+(5-3,944)^{2}+(24-4,889)^{2}+(0,11-0,706)^{2}}$ & 4,379 \\
\hline 20 & $\sqrt{(0-7,333)^{2}+(0-3,944)^{2}+(23-4,889)^{2}+(0,17-0,706)^{2}}$ & 2,480 \\
\hline 21 & $\sqrt{(4,5-7,333)^{2}+(2-3,944)^{2}+(2-4,889)^{2}+(0,3-0,706)^{2}}$ & 22,946 \\
\hline 22 & $\sqrt{(20-7,333)^{2}+(1-3,944)^{2}+(3-4,889)^{2}+(1-0,706)^{2}}$ & 28,700 \\
\hline 23 & $\sqrt{(5-7,333)^{2}+(1-3,944)^{2}+(5-4,889)^{2}+(0,12-0,706)^{2}}$ & 20,061 \\
\hline 24 & $\sqrt{(3,5-7,333)^{2}+(1-3,944)^{2}+(2-4,889)^{2}+(0,125-0,706)^{2}}$ & 22,816 \\
\hline 25 & $\sqrt{(3,5-7,333)^{2}+(3-3,944)^{2}+(2-4,889)^{2}+(2,4-0,706)^{2}}$ & 22,991 \\
\hline 26 & $\sqrt{(12-7,333)^{2}+(8-3,944)^{2}+(6-4,889)^{2}+(0,68-0,706)^{2}}$ & 22,599 \\
\hline 27 & $\sqrt{ }(2-7,333)^{2}+(2-3,944)^{2}+(3-4,889)^{2}+(0,15-0,706)^{2}$ & 21,724 \\
\hline 28 & $\sqrt{(10-7,333)^{2}+(4-3,944)^{2}+(3-4,889)^{2}+(0,22-0,706)^{2}}$ & 23,560 \\
\hline 29 & $\sqrt{(9-7,333)^{2}+(3-3,944)^{2}+(8-4,889)^{2}+(0,84-0,706)^{2}}$ & 18,512 \\
\hline 30 & $\sqrt{ }(11-7,333)^{2}+(3-3,944)^{2}+(7-4,889)^{2}+(0,31-0,706)^{2}$ & 20,290 \\
\hline 31 & $\sqrt{(6-7,333)^{2}+(2-3,944)^{2}+(6-4,889)^{2}+(0,12-0,706)^{2}}$ & 19,312 \\
\hline 32 & $\sqrt{ }(4,5-7,333)^{2}+(3-3,944)^{2}+(12-4,889)^{2}+(0,18-0,706)^{2}$ & 13,222 \\
\hline 33 & $\sqrt{(10-7,333)^{2}+(3-3,944)^{2}+(9-4,889)^{2}+(0,14-0,706)^{2}}$ & 18,064 \\
\hline 34 & $\sqrt{(12-7,333)^{2}+(5-3,944)^{2}+(5-4,889)^{2}+(2,05-0,706)^{2}}$ & 22,837 \\
\hline 35 & $\sqrt{(10-7,333)^{2}+(13-3,944)^{2}+(9-4,889)^{2}+(1,19-0,706)^{2}}$ & 21,471 \\
\hline 36 & $\sqrt{(9-7,333)^{2}+(13-3,944)^{2}+(3-4,889)^{2}+(1,36-0,706)^{2}}$ & 25,870 \\
\hline 37 & $\sqrt{(0-7,333)^{2}+(1-3,944)^{2}+(1-4,889)^{2}+(1,6-0,706)^{2}}$ & 23,782 \\
\hline 38 & $\sqrt{(0-7,333)^{2}+(3-3,944)^{2}+(2-4,889)^{2}+(0,39-0,706)^{2}}$ & 22,797 \\
\hline
\end{tabular}

Langkah selanjutnya, data diatas akan dikelompokkan ke dalam 2 kelompok seperti pada langkah sebelumnya dalam menghitung iterasi 1. Lebih jelasnya dapat dilihat pada tabel dibawah ini:
Tabel 11 Pengelompokan Data 2

\begin{tabular}{|c|c|c|}
\hline No. & $\begin{array}{c}\text { Cluster } \\
1\end{array}$ & $\begin{array}{c}\text { Cluster } \\
2\end{array}$ \\
\hline 1 & 1 & 0 \\
\hline 2 & 1 & 0 \\
\hline 3 & 1 & 0 \\
\hline 4 & 1 & 0 \\
\hline 5 & 1 & 0 \\
\hline 6 & 1 & 0 \\
\hline 7 & 1 & 0 \\
\hline 8 & 1 & 0 \\
\hline 9 & 1 & 0 \\
\hline 10 & 1 & 0 \\
\hline 11 & 1 & 0 \\
\hline 12 & 1 & 0 \\
\hline 13 & 1 & 0 \\
\hline 14 & 1 & 0 \\
\hline 15 & 1 & 0 \\
\hline 16 & 1 & 0 \\
\hline 17 & 1 & 0 \\
\hline 18 & 1 & 0 \\
\hline 19 & 1 & 0 \\
\hline 20 & 1 & 0 \\
\hline 21 & 0 & 1 \\
\hline 22 & 0 & 1 \\
\hline 23 & 0 & 1 \\
\hline 24 & 0 & 1 \\
\hline 25 & 0 & 1 \\
\hline 26 & 0 & 1 \\
\hline 27 & 0 & 1 \\
\hline 28 & 0 & 1 \\
\hline 29 & 0 & 1 \\
\hline 30 & 0 & 1 \\
\hline 31 & 0 & 1 \\
\hline 32 & 0 & 1 \\
\hline 33 & 0 & 1 \\
\hline 34 & 0 & 1 \\
\hline 35 & 0 & 1 \\
\hline 36 & 0 & 1 \\
\hline 37 & 0 & 1 \\
\hline 38 & 0 & 1 \\
\hline
\end{tabular}

Dapat dilihat bahwa hasil pengelompokan data $1=$ pengelompokan data 2, sehingga tidak perlu melakukan iterasi lagi. Apabila nilai pada iterasi 2 ada yang berbeda dengan iterasi 1, maka harus dilakukan perhitungan iterasi kembali seperti langkah diatas. 
Tabel 10 Iterasi 2

\begin{tabular}{|c|c|c|c|c|c|c|c|c|}
\hline No. & $\begin{array}{c}\text { Produk } \\
\text { Kemasan }\end{array}$ & Lemak & Protein & Gula & Natrium & $\begin{array}{c}\text { Cluster } \\
1\end{array}$ & $\begin{array}{c}\text { Cluster } \\
2\end{array}$ & Jarak Terdekat \\
\hline 1 & Good Day & 3 & 0 & 22 & 0,055 & 3,492 & 18,098 & 3,492 \\
\hline 2 & White Coffee & 2 & 4 & 21 & 0,065 & 4,631 & 16,983 & 4,631 \\
\hline 3 & Golda & 2 & 2 & 15 & 0,105 & 9,754 & 11,611 & 9,754 \\
\hline 4 & Kopiko Kopi & 3 & 3 & 23 & 0,270 & 2,980 & 18,651 & 2,980 \\
\hline 5 & $\begin{array}{l}\text { Nescafe } \\
\text { Origin }\end{array}$ & 2 & 3 & 18 & 0,115 & 6,950 & 14,198 & 6,950 \\
\hline 6 & $\begin{array}{l}\text { Del Monte } \\
\text { Quality } \\
\text { Vanilla } \\
\end{array}$ & 3 & 2 & 21 & 0,105 & 4,159 & 16,807 & 4,159 \\
\hline 7 & Pepsi Blue & 0 & 0 & 34 & 0,015 & 9,474 & 30,286 & 9,474 \\
\hline 8 & Fruit Tea & 0 & 0 & 27 & 0,035 & 2,924 & 23,637 & 2,924 \\
\hline 9 & Stee & 0 & 0 & 26 & 0,025 & 2,225 & 22,704 & 2,225 \\
\hline 10 & $\begin{array}{l}\text { Ichitan Thai } \\
\text { Tea Milk } \\
\text { Coffee }\end{array}$ & 5 & 4 & 29 & 0,220 & 6,318 & 24,229 & 6,318 \\
\hline 11 & Kratingdaeng & 0 & 1,5 & 25 & 0,000 & 1,276 & 21,557 & 1,276 \\
\hline 12 & Fanta Anggur & 0 & 0 & 25 & 0,055 & 1,830 & 21,777 & 1,830 \\
\hline 13 & Sprite & 0 & 0 & 25 & 0,045 & 1,830 & 21,777 & 1,830 \\
\hline 14 & Coca Cola & 0 & 0 & 27 & 0,015 & 2,924 & 23,637 & 2,924 \\
\hline 15 & Nutri Boost & 1 & 2 & 33 & 0,160 & 8,331 & 28,886 & 8,331 \\
\hline 16 & $\begin{array}{l}\text { Minute Maid } \\
\text { Pulpy }\end{array}$ & 0 & 0 & 27 & 0,045 & 2,924 & 23,636 & 2,924 \\
\hline 17 & $\begin{array}{l}\text { Fresh Tea } \\
\text { Marquisa }\end{array}$ & 0 & 0 & 26 & 0,030 & 2,225 & 22,704 & 2,225 \\
\hline 18 & Isoplus & 0 & 0 & 23 & 0,160 & 2,480 & 19,941 & 2,480 \\
\hline 19 & $\begin{array}{l}\text { Indomilk } \\
\text { Good To Go }\end{array}$ & 3,5 & 5 & 24 & 0,110 & 4,379 & 19,529 & 4,379 \\
\hline 20 & Coolant & 0 & 0 & 23 & 0,170 & 2,480 & 19,941 & 2,480 \\
\hline 21 & $\begin{array}{l}\text { Oishi Ring } \\
\text { Bee }\end{array}$ & 4,5 & 2 & 2 & 0,300 & 22,946 & 4,508 & 4,508 \\
\hline 22 & $\begin{array}{l}\text { Stik Kentang } \\
\text { Renova }\end{array}$ & 20 & 1 & 3 & 0,530 & 28,700 & 13,142 & 13,142 \\
\hline 23 & Gery Saluut & 5 & 1 & 5 & 0,120 & 20,061 & 3,804 & 3,804 \\
\hline 24 & $\begin{array}{l}\text { Malkis } \\
\text { Seaweed }\end{array}$ & 3,5 & 1 & 2 & 0,125 & 22,816 & 5,661 & 5,661 \\
\hline 25 & $\begin{array}{l}\text { Hup Seng } \\
\text { Cream } \\
\text { Creackers }\end{array}$ & 3,5 & 3 & 2 & 2,400 & 22,991 & 5,177 & 5,177 \\
\hline 26 & Indomie & 12 & 8 & 6 & 0,680 & 22,599 & 6,282 & 6,282 \\
\hline 27 & $\begin{array}{l}\text { Cap PingPong } \\
\text { Sugar } \\
\text { Creakers }\end{array}$ & 2 & 2 & 3 & 0,150 & 21,724 & 6,009 & 6,009 \\
\hline 28 & $\begin{array}{l}\text { Shoon Fatt } \\
\text { Sugar } \\
\text { Creakers } \\
\end{array}$ & 10 & 4 & 3 & 0,220 & 23,560 & 3,304 & 3,304 \\
\hline 29 & $\begin{array}{l}\text { Lavish Peanut } \\
\text { Butter } \\
\text { Sandwich }\end{array}$ & 9 & 3 & 8 & 0,840 & 18,512 & 3,656 & 3,656 \\
\hline 30 & Naiyu Jagung & 11 & 3 & 7 & 0,310 & 20,290 & 4,353 & 4,353 \\
\hline 31 & $\begin{array}{l}\text { Mega } \\
\text { Chocolate }\end{array}$ & 6 & 2 & 6 & 0,120 & 19,312 & 2,671 & 2,671 \\
\hline 32 & Hello Panda & 4,5 & 3 & 12 & 0,180 & 13,222 & 7,731 & 7,731 \\
\hline 33 & Pocky & 10 & 3 & 9 & 0,140 & 18,064 & 5,022 & 5,022 \\
\hline 34 & $\begin{array}{l}\text { Ajinomoto } \\
\text { YumYum }\end{array}$ & 12 & 5 & 5 & 2,050 & 22,837 & 4,971 & 4,971 \\
\hline 35 & Sukses & 10 & 13 & 9 & 1,190 & 21,471 & 10,308 & 10,308 \\
\hline 36 & Sarimi & 9 & 13 & 3 & 1,360 & 25,870 & 9,422 & 9,422 \\
\hline 37 & $\begin{array}{l}\text { Bihun Rose } \\
\text { Brand }\end{array}$ & 0 & 1 & 1 & 1,600 & 23,782 & 8,853 & 8,853 \\
\hline 38 & $\begin{array}{l}\text { Sarimi Mie } \\
\text { Gelas }\end{array}$ & 0 & 3 & 2 & 0,390 & 22,797 & 7,970 & 7,970 \\
\hline
\end{tabular}




\section{Pengolahan Data Dengan RStudio}

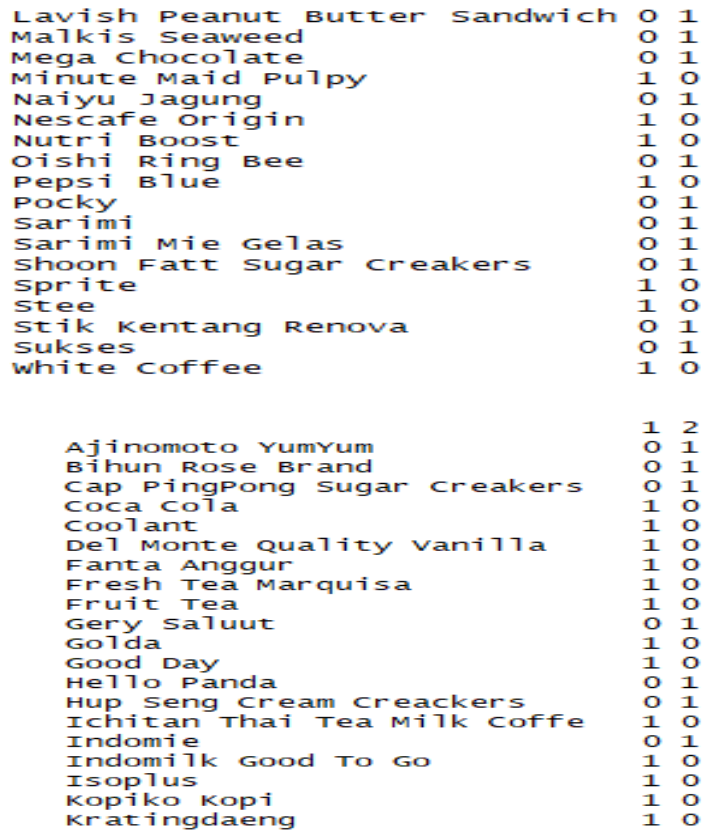

Gambar 1 Pengelompokan data



Gambar 2 Scatter Plot pengolahan data dengan RStudio

\section{KESIMPULAN DAN SARAN}

Berdasarkan hasil yang dicapai terkait dengan penelitian pengelompokkan produk kemasan yang harus dihindari penderita diabetes, maka dapat disimpulkan bahwa:

1. Pengelompokkan data produk kemasan berdasarkan informasi nilai gizi dari setiap produk yang meliputi lemak, protein, gula dan natrium yang difokuskan untuk gula dan natrium dibagi menjadi 2 yaitu kelompok produk dengan tinggi gula rendah natrium yang berjumlah 20 produk dan kelompok produk rendah gula tinggi natrium yang berjumlah 18 produk.

2. Sebanyak 20 produk yang masuk kedalam kelompok tinggi gula rendah natrium harus dihindari penderita penyakit diabetes. Sedangkan 18 produk yang masuk kedalam kelompok tinggi natrium rendah gula bisa dikonsumsi oleh penderita penyakit diabetes.

3. Algoritma K-Means Clustering ini sangat membantu dalam pengelompokkan suatu data berdasarkan karakterisitik suatu data dengan pengambilan centroid secara acak di langkah awal dan iterasi yang dilakukan berulang hingga nilai cluster tidak berubah.

\section{DAFTAR PUSTAKA}

[1] Pramadhani, Aline Embun, Setiadi, Tedy. 2014. Penerapan Data Mining Untuk Klasifikasi Prediksi Penyakit ISPA (Infeksi Saluran Pernapasan Akut) Dengan Algoritma Decision Tree (ID3). Jurnal Sarjana Teknik Informatika Volume 2 Nomor 1.

[2] Efendi, Muhamad Subhan, Wibawa, Helmie Arif. 2018. Prediksi Penyakit Diabetes Menggunakan Algoritma ID3 dengan Pemilihan Atribut Terbaik (Diabetes Prediction using ID3 Algorithm with Best Attribute Selection). JUITA p-ISSN: 2086-9398 (print); e-ISSN: 2579-9801 (online); Volume VI, Nomor 1.

[3] Asroni, Ronald Adrian. 2015. Penerapan Metode K-Means Untuk Clustering Mahasiswa Berdasarkan Nilai Akademik Dengan Weka Interface Studi Kasus Pada Jurusan Teknik Informatika UMM Magelang. Jurnal Ilmiah Semesta Teknika Vol. 18, No. 1,76-82

[4] Widodo, dan Wahyuni, Dina. 2017. Implementasi Algoritma K-Means Clustering Untuk Mengetahui Bidang Skripsi Mahasiswa Multimedia Pendidikan Teknik Informatika Dan Komputer Universitas Negeri Jakarta. Jurnl PINTER Vol. 1, No. 2

[5] Sucipto, Hadi, dkk. 2017. SISTEM PENDUKUNG KEPUTUSAN PENERIMAAN SISWA BARU DAN PENJURUSAN PADA SEKOLAH MENENGAH KEJURUAN(SMK). JURNAL EKONOMI DAN TEKNIK INFORMATIKA VOL. 5 NO. 2

[6] Muningsih, Elli, \& Kiswati, Sri. 2015. . Penerapan Metode K-Means Untuk Clustering Produk Online Shop Dalam Penentuan Stok Barang. Jurnal Bianglala Informatika Vol. , No. 1

[7] Ndruru, Efroni \& Limbong, Riswan. 2018. Implementasi Data Mining Dalam Pengelompokkan Jurusan yang Diminati Siswa SMK Negeri 1 Lolowa'u menggunakan Metode Clustering. MEANS (Media Informasi Analisa dan Sistem) p-ISSN: 2548-6985, e-ISSN: 2599-3089; Volume 3 No. 2. 